Fleischschafen an Länge zu und sind weniger voll ausgebildet. Vor allem bei Merkmalen der Verfettung wirkt sich der steigende Finnanteil aus. Sowohl der Körperfettanteil als auch die Menge des Nierenfettes zeigen eine deutliche Erhöhung.

Der teilweise Ersatz von Finnschafgenen durch Milchschafgene wirkt sich bei diesen Merkmalen positiv aus.

\title{
Productivity of FINNISH LANDRACE $\times$ DORSET HORN EWES
}

J. J. Robinson, C. Fraser, J. C. Gill and I. McHattie. - The Rowett Research Institute Bucksburn, Aberdeen, Scotland.

Results are presented for the breeding performance of Finn $\times$ Dorset Horn ewe lambs or ewes in a once per year breeding system. Conception rate at a mean age of $238 \pm 9.4$ days was 91.7 per cent and mean litter size I.52. Corresponding values for $294 \pm$ II.4 days were 94.3 per cent and 1.70. An interaction between time of year of birth and onset of puberty was observed, with ewe lambs boin as late as November showing behavioural oestrus before the end of the breeding season. Ewes bred once per year had a mean litter size of 2.34.

Results are also given for a frequent breeding experiment in which two flocks each of 48 ewes were repeatedly subjected to artificial daylength regimes, weaned after one month of lactation and synchronised in cestrus by using a synthetic progestagen. Total annual production was 3.5 lambs per ewe.

The amounts and patter $n$ of food intake during the reproductive cycle required to achieve this level of production are presented.

The results of experiments designed to show whether the increased frequency of breeding and high level of production achieved under conditions of artificial daylength control could be achieved under natural conditions are presented. In these studies a conception rate of 92.8 per cent was obtained in ewes bred during the normal period of anoestrous using 400 I.U. of pregnant mares serum gonadotrophin at pessary withdrawal.

Mean daily lamb growth rate and estimated milk yield in twin bearing ewes given ad libitum a diet containing to MJ metabolizable energy per $\mathrm{kg}$ was $0.29 \pm 0.05$ and $2.93 \pm 0.5 \mathrm{I} \mathrm{kg}$ respectively.

\section{LE CROISEMENT ROMANOV ET FINNOIS SUR L'ARAGONAISE : RÉSULTATS PRÉLIMINAIRES D'ENGRAISSEMENT ET DE REPRODUCTION}

M. Valls Ortiz, Y. Cognie, M. D. Valdemoro et J. Hallauer. - C.R.I.D.A.-o3, I.N.I.A. Apartado 202, Zaragoza, España.

Les performances des $\mathrm{F}_{\mathbf{1}}$ obtenues avec les races Romanov et Finnoise sur un troupeau de too brebis Aragonaise Rasa (p. v. 45 kg), sont étudiées depuis I974, dans le cadıe des essais d'utilisation de ces races prolifiques en milieu Méditerranéen.

D'après les résultats constatés, il semblerait que l'utilisation du Romanov ou de Finnois sur une race rustique de format moyen permet une amélioration de la croissance par rapport à la race 1 ustique. Dans le cas présent, l'avantage a été de l'ordra de 15-20 p. Ioo pour le RO $\times$ RA et de Io-I 5 p. Ioo pour le FI $\times$ RA. Le croisement dans ces conditions, bien que sans améliorer natablement l'aspect des carcasses, permettrait l'obtention de carcasses plus lourdes pour un même degré de maturité.

Che les femelles, la précocité sexuelle (un mois d'avance au r er œstrus) et surtout le taux d'ovulation, sont nettement améliorés par effet du croisement, avec un léger avantage des crossées RO sur les croisées FI. Le taux d'ovulation moyen au cours d'une saison à l'âge de 2 ans, a été de $\mathrm{I}, 73, \mathrm{I}, 60, \mathrm{I}, 06$ respectivement pour les croisées RO, FI et les RA pures.

La saison sexuelle bien que de durée à peu près similaire pour les trois génotypes, semble pourtant, commencer et finir plus tard chez les croisées que chez les Rasa.

\section{REPRODUCTIVE EFFICIENCY OF ICELAND SHEEP \\ I. PUBerty AND EARLy REPRODUCTIVE PERFormance}

O. R. Dyrmundsson. - The Agricultural College Hvanneyri, Hvanneyri, Iceland.

Lambs of the Iceland breed of sheep are found to be early maturing. The level of reproductive efficiency in the flock is raised by breeding from ewe lambs and by using ram lambs for mating. The reproductive potential of the lamb is increasingly being realized by farmers in Iceland. 
Icelandic lambs are normally born in May. Most of the ewe lambs experience their first cestrus from late November to late December aged 6,5-7,5 months and weighing $30-45 \mathrm{~kg}$. They may exhibit oestrus 4-5 times on the average during the breeding season, the mean oestrous cycle length being 16 days. It has now become a common practice to breed from ewe lambs weighing $35 \mathrm{~kg}$ or more in December so that they will lamb in May at 12 months of age. Normally some 70 per cent of all ewe lambs exposed to rams will conceive. They have an average gestation period of $\mathrm{I}_{4} \mathrm{I}$ days. The growth rate of their lambs from birth to weaning at 4 months exceeds that of twins reared by adult ewes. Early breeding does not have any detrimental effects on the overall lifetime productivity of the ewe provided well grown and adequately nourished ewe lambs are selected for breeding.

Icelandic ram lambs attain puberty, judged by their anatomical development, at an early age of 4-5 months and they are used successfully for breecling in December when 7 months of age.

\section{MODEL EXPERIMENTS FOR DEVELOPING SHEEP POPULATIONS}

I. INCREASE OF PROLIFICACY PER LAMBING

\section{Veress, J. Stosz and L. Lovas. - Kaposvár (Hungary).}

The authors examined the possibility of developing such a population of great prolificacy and requiring intensive breeding, the genetic parameters $c f$ which are the following: first lambing about the age of one year, at least 3 lambs per lambing, lambing interval between 6 ans 8 months.

Newertheless, it could be achieved, that I 3 of I $7_{7}$ aboundantly foraged tegs should lamb at the average age of 282 days, their lambs were not viable enough.

Data were collected concerning the reproductive quality of 37 Finnish tegs imported from Finnland, 3o Romanov tegs imported from the Soviet Union and their progeny, originating from own breeding. The lambing rate of tegs, having lambed for the first time about at the age of one year was smaller than those of having lambed for the first time at an older age, but the earlier taking into breeding did not influence disadvantageously their later productivity and prolificacy.

In the average of Ir 6 lambings the Finnish ewes had 2,00 lambs and the Romanov ones in the average of 159 lambings 2,42 lambs. Their lactation milk yield proved to be insufficient for the lambs, therefore the growth of them was not satisfying. Especially the $\mathrm{F}_{1}$ lambs of Finnish mothers, originating from Romanov rams, were raising more poorly during the lactation period and could less compensate the lag after the weaning, too. Therefore it is not worth leaving more than 2 lambs with the mother and the lambs above this number must be raised artificially with reconstituted milk.

\section{MODEL EXPERIMENTS FOR DEVELOPING SHEEP FOPULATIONS} II. SHORTENING OF THE INTERLAMBING PERIOD

L. Veress and J. STosz. - Kaposvár, Hungary.

Both the Finnish and the Romanov breed, as a selection basis, are suited for the development of such an ewe population, which can fulfill the requested genetic parameters. But the development and application of breeding and feeding technologies is of fundamental importance. The special acclimatization ability of the Romanov breed must be emphasised. It can well tolerate the rearing in great - I oo-zoo heads - groups.

Not more than two lambs should be left together with the ewe.

The feeding of lambs with milk or milk substitute, whether they are raised artificially or suckled by the mother, is not reasonable over the age of $35^{-45}$ days. At this age they must be weaned.

Concerning the period of re-lambing with respect to both breeds, so great individual differences were obtained, that it can be advised for the future to put the examination of heredity and repeatability of this trait on the agenda.

The $h^{2}$ values obtained for the prolificacy of sheep, must be revised.

IMPROVEMENT OF REPRODUCTION PERFORMANCE BY INTRODUCING FINNISH LANDRACE GENES INTO MERINOLANDSCHAF (WÜRTTEMBERG-MERINO)

G. NitTeR. - Institut für Tierhaltung und Tievzüchtung der Universität Hohenheim D-7000 Stuttgart 70, Deutschland.

The change of both, market requirement and husbandry techniques in the sheep industry of the FRG call for investigation of genetic alternatives to the most widespread breed in the country, the Merinolandschat (Wurttemberg Merino). In a first experiment from I969 to I973, 